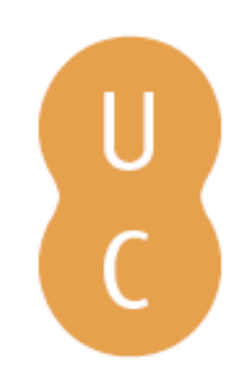

\title{
pompalina
}

\section{Estimation of live fuel moisture content of shrubland using MODIS and Sentinel-2 images}

\begin{tabular}{|c|c|}
\hline Autor(es): & $\begin{array}{l}\text { Marino, Eva; Guillén-Climent, Mariluz; Algeet, Nur; Tomé, José Luis; } \\
\text { Hernando, Carmen }\end{array}$ \\
\hline Publicado por: & Imprensa da Universidade de Coimbra \\
\hline $\begin{array}{l}\text { URL } \\
\text { persistente: }\end{array}$ & URI:http://hdl.handle.net/10316.2/44539 \\
\hline DOI: & DOI:https://doi.org/10.14195/978-989-26-16-506_22 \\
\hline Accessed : & 26-Apr-2023 12:24:18 \\
\hline
\end{tabular}

A navegação consulta e descarregamento dos títulos inseridos nas Bibliotecas Digitais UC Digitalis, UC Pombalina e UC Impactum, pressupõem a aceitação plena e sem reservas dos Termos e Condições de Uso destas Bibliotecas Digitais, disponíveis em https://digitalis.uc.pt/pt-pt/termos.

Conforme exposto nos referidos Termos e Condições de Uso, o descarregamento de títulos de acesso restrito requer uma licença válida de autorização devendo o utilizador aceder ao(s) documento(s) a partir de um endereço de IP da instituição detentora da supramencionada licença.

Ao utilizador é apenas permitido o descarregamento para uso pessoal, pelo que o emprego do(s) título(s) descarregado(s) para outro fim, designadamente comercial, carece de autorização do respetivo autor ou editor da obra.

Na medida em que todas as obras da UC Digitalis se encontram protegidas pelo Código do Direito de Autor e Direitos Conexos e demais legislação aplicável, toda a cópia, parcial ou total, deste documento, nos casos em que é legalmente admitida, deverá conter ou fazer-se acompanhar por este aviso.

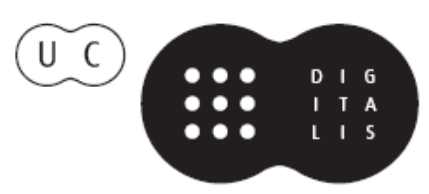




\section{ADVANCES IN}

\section{FOREST FIRE RESEARCH}

\section{8}

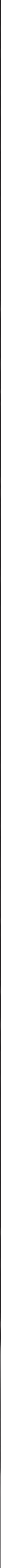




\title{
Estimation of live fuel moisture content of shrubland using MODIS and Sentinel-2 images
}

\author{
Eva Marino $^{1 *}$; Mariluz Guillén-Climent ${ }^{1}$; Nur Algeet ${ }^{1}$; José Luis Tomé ${ }^{1}$; Carmen Hernando ${ }^{2}$ \\ ${ }^{1}$ AGRESTA Sociedad Cooperativa. C/Duque de Fernán Núñez 2, 28012 Madrid. \\ \{emarino@agresta.org*\} \\ ${ }^{2}$ INIA, Forest Research Centre, Department of Silviculture and Forest Management, Forest fire \\ laboratory. Crta. A Coruña Km 7.5, 28040 Madrid, Spain
}

\begin{abstract}
Live fuel moisture content (LFMC) is a critical parameter affecting vegetation flammability and fire behaviour. Reliable and updated estimations of LFMC are needed by fire managers for operational wildfire risk assessment. However, detailed and constant monitoring of LFMC in the field is costly and timeconsuming. Remote sensing technologies are an important source of geospatial data that can provide spectral information related to LFMC at different temporal and spatial resolution. In this study, we used a database of LFMC monitoring sampled during 2016 and 2017 (n=81) in a monospecific Cistus ladanifer L. shrubland in Madrid region (Central Spain). C. ladanifer is a representative shrub species commonly found in Mediterranean fire-prone areas, and has been already identified as an indicator species for wildfire risk assessment by different regional fire services. A set of spectral indices (SI) derived from MODIS images (MOD09GA) were calculated at $500 \mathrm{~m}$ resolution and compared with field data. We also used Sentinel-2 images for SI retrieval at $20 \mathrm{~m}$ resolution with the aim of addressing the scale problem between field sampling site and the low spatial resolution of MODIS data. The same SI were calculated adapting formulations to Sentinel-2 spectral resolution. The timelag between images and field sampling date was limited to a maximum of 2 days for operational purposes. Multiple linear regression analysis was used to assess the potential of SI for LFMC estimation, comparing results for both type of images. Most of the SI tested showed a significant correlation with LFMC data derived from MODIS $(n=62)$ and Sentinel-2 $(n=35)$. For MODIS, the best indices were EVI, VARI, and VIGREEN $\left(\mathrm{R}^{2}=0.82\right.$, MAE $\left.=12 \%\right)$, followed by NDVI and SAVI $\left(\mathrm{R}^{2}=0.76\right.$, $\mathrm{MAE}=14 \%)$. For Sentinel-2, the best indices were VARI $\left(\mathrm{R}^{2}=0.72, \mathrm{MAE}=13 \%\right)$, EVI $\left(\mathrm{R}^{2}=0.71, \mathrm{MAE}=13 \%\right)$, VIGREEN $\left(\mathrm{R}^{2}=0.67, \mathrm{MAE}=14 \%\right)$ and $\mathrm{NDVI}\left(\mathrm{R}^{2}=0.62, \mathrm{MAE}=14 \%\right)$. In both cases, a significant multivariate model was found including NDVI and VARI, with a slight increase in prediction accuracy compared to simple regression models $\left(\mathrm{R}^{2}=0.85\right.$ with $\mathrm{MAE}=11 \%$ for MODIS, and $\mathrm{R}^{2}=0.76, \mathrm{MAE}=12 \%$ for Sentinel-2). Our findings indicate that MODIS and Sentinel-2 images provide similar results for the SI tested, and that both satellites can be used for near real-time estimation of LFMC in C. ladanifer shrubland. The proposed models can be used to improve monitoring of the variability of LFMC during the year, as well as helping the integration of remote sensing data on wildfire danger rating systems.
\end{abstract}

Keywords: Live fuel moisture content; MODIS; Sentinel-2; remote sensing; Cistus ladanifer

\section{Introduction}

Live fuel moisture content (LFMC) is a critical parameter affecting vegetation flammability and fire behaviour (Denisson and Moritz 2009, Marino et al. 2012). Moisture of both live and dead components of vegetation are often required as input to predict fire behaviour in wildfire simulation models. Reliable and updated estimations of LFMC are also needed by fire managers for wildfire danger rating (Chuvieco et al. 2014).

Extreme weather is becoming more frequent due to climate change thus extending the fire season in most Mediterranean areas (Ruffault et al. 2018), where fire regimes have shifted from fuel-limited 
to drougth-driven in the last decades (Pausas and Fernández-Múñoz, 2012). Dead fuel moisture, especially fine fuels, is generally more easily determined from weather variables as it relies on fuel size, local atmospheric conditions and precipitation (Viney et al. 1991, Nolan et al. 2016). Conversely, LFMC is more difficult to estimate as it strongly depends on physiological and phenological characteristics of each species that may be mostly driven by medium-term meteorological conditions (Yebra et al. 2013). Fire management services are spending important amount of resources on sampling vegetation for LFMC estimation to be used in pre-fire alert system and fire-fighting operations. However, detailed and constant monitoring of LFMC in the field is costly and timeconsuming. Therefore, fire management services often focus on indicator species that are relevant for wildfire prevention systems.

Previous studies demonstrate the ability of remote sensing data for LFMC estimation (Chuvieco et al. 2004, Garcia et al. 2008, Yebra et al. 2008). Different espectral, spatial and temporal resolutions are available depending on the type of sensor used. MODIS is one of most commonly used optical sensors due to its high temporal resolution. Empirical models were proposed by many authors to estimate LFMC from a combination of different espectral indices derived from MODIS images (Dennison et al. 2005, Stow et al. 2006, Peterson et al. 2008, Caccamo et al. 2012). Other authors used radiative transfer models (RTM), a more complex method based on physical approaches from simulations that can provide more robust LFMC estimations independent of site specificities (Hao and Qu 2007, Yebra et al. 2008, 2013, Yebra and Chuvieco 2009, Jurdao et al. 2013). Both methods applied on MODIS images provide spectral information at a coarse spatial resolution, which may limit its use in small scale sampling areas or heterogenenous vegetation. More recently, some authors assessed the potential of microwave remote sensing as an alternative for LFMC estimation, obtaining moderate results compared to optical indices derived from MODIS (Tanase et al. 2015, Fan et al. 2018). Hence, further research is still needed to provide fire managers with operational models and tools for accurate LFMC prediction that could be included in operational fire danger rating systems (Yebra et al. 2013). The new generation of Sentinel-2 sensors provide similar spectral information to MODIS images but at higher spatial resolution, which offers an opportunity to improve LFMC estimations for operational purposes.

The objetive of this work was to compare the ability of two different type of satellites, MODIS and Sentinel-2, for LFMC estimation. Research is focused on monospecific Cistus ladanifer shrubland. $C$. ladanifer is a representative shrub species commonly found in Mediterranean fire-prone areas, and has been already identified as an indicator species for wildfire risk assessment by different regional fire services.

\section{Methods}

\subsection{Field samples and laboratory protocol}

A database of LFMC monitored in C. ladanifer shrubland was used as reference data. The study area is a 45 ha of monospecific shrubland located in Madrid region (Central Spain) where samples of C. ladanifer were systematically collected during 2016 and $2017(\mathrm{n}=81)$. Samples of live fine fuels, including leaves and terminal twigs, were collected according to a field protocol defined by INIA forest fire laboratory. Sampling frequency varied along the year, starting in spring 2016, with an increased frequency of up to three days during the summer, weekly during spring and autum, and biweekly in winter.

Field samples were immediately conducted to INIA forest fire laboratory in sealed plastic pots to prevent moisture losses after cutting. Fresh samples were weighted daily and then oven-dried (24h, $100^{\circ}$ ) for moisture content estimation. LFMC was calculated as the percentage of water content of vegetation on a dry-weight basis following the equation: 


$$
L F M C=\left(\frac{W_{f}-W_{d}}{W_{d}}\right) \times 100
$$

where $\mathrm{W}_{\mathrm{f}}$ is the fresh weight and $\mathrm{W}_{\mathrm{d}}$ the dry weight of each sample.

\subsection{Remote sensing data}

\subsubsection{Image selection and preprocessing}

Images from two different type of sensors were used: MODIS and Sentinel-2. Terra MODIS images corresponded to MOD09GA, a daily product available at $500 \mathrm{~m}$ and $1000 \mathrm{~m}$ resolution. Sentinel-2 images corresponded to both satellites $2 \mathrm{~A}$ and $2 \mathrm{~B}$, providing information from $10 \mathrm{~m}$ to $60 \mathrm{~m}$ depending on the spectral band.

Time series from april 2016 to october 2017 were used in this study for both types of images. Since MODIS and Sentinel-2 products used are 1-day images, i.e. not composite products, the timelag between images and sampling date was limited to a maximum of 2 days in order to compare available images with field data. A total of 62 cloud-free MODIS images were selected for 2016-2017. As Sentinel-2 is a more recent satellite, only 8 images were available for 2016 compared to 27 for 2017, resulting in a total of 35 for the study period.

The MOD09GA product obtained by the Terra MODIS satellite corresponded to atmospherically corrected surface reflectance. The images were downloaded from the NASA Land Processess Distributed Active Archive Center (LP DAAC, https://lpdaac.usgs.gov/).

Level 1C Sentinel-2 imagery was downloaded from the European Space Agency (ESA) and preprocessed with Sen2Cor software (Louis et al. 2016) developed by ESA. This software performs the tasks of Atmospheric Correction and Scene Classification of Level 1C input data. Level 2A outputs are Bottom-Of-Atmosphere (BOA) corrected reflectance images.

\subsubsection{Spectral indices}

A set of spectral indices (SI) derived from MODIS images were calculated at $500 \mathrm{~m}$ resolution (Table 1), including Normalized Difference Vegetation Index (NDVI), Normalized Difference Infrared Index with band 6 and 7 (NDII6, NDII7), Global Vegetation Moisture Index (GVMI), Normalized Difference Water Index (NDWI), Enhanced Vegetation Index (EVI), Soil Adjusted Vegetation Index (SAVI), Visible Atmospherically Resistant Index (VARI), Vegetation Index Green, or Normalized Green Red Difference (VIGREEN).

The Sentinel-2 satellites include a high-resolution optical sensor that operates in 13 bands between the visible and the SWIR. Spatial resolution is $10 \mathrm{~m}$ for visible and NIR bands, $20 \mathrm{~m}$ for red-edge and SWIR bands, and $60 \mathrm{~m}$ for atmospheric bands. The same MODIS indices (except GVMI and NDWI) were calculated for Sentinel-2 images at a $20 \mathrm{~m}$ pixel resolution, adapting formulation to the spectral resolution of Sentinel-2 when needed.

For MODIS images, SI values corresponded to the weighted mean of pixel values according to each pixel surface inside the sampling area. For Sentinel-2, SI values were the average values of the pixels completely included inside the sampling area. 
Table 1 - Spectral indices used to estimate LFMC from MODIS data. $\rho_{x}$ is reflectance in MODIS band $x$.

\begin{tabular}{|c|c|c|}
\hline Index & Formulation & Reference \\
\hline $\begin{array}{l}\text { Normalized Difference Vegetation } \\
\text { Index }\end{array}$ & $N D V I=\frac{\rho_{2}-\rho_{1}}{\rho_{2}+\rho_{1}}$ & Rouse et al. (1974) \\
\hline $\begin{array}{l}\text { Normalized Difference Infrared Index } \\
\text { (band 6) }\end{array}$ & $N D I I 6=\frac{\rho_{2}-\rho_{6}}{\rho_{2}+\rho_{6}}$ & Hardisky et al. (1983) \\
\hline $\begin{array}{l}\text { Normalized Difference Infrared Index } \\
\text { (band 7) }\end{array}$ & $N D I I 7=\frac{\rho_{2}-\rho_{7}}{\rho_{2}+\rho_{7}}$ & Hardisky et al. (1983) \\
\hline Global Vegetation Moisture Index & $G V M I=\frac{\left(\rho_{2}+0.1\right)-\left(\rho_{6}+0.02\right)}{\left(\rho_{2}+0.1\right)+\left(\rho_{6}+0.02\right)}$ & Ceccato et al. (2002) \\
\hline Normalized Difference Water Index & $N D W I=\frac{\rho_{2}-\rho_{5}}{\rho_{2}+\rho_{5}}$ & Gao (1996) \\
\hline Enhanced Vegetation Index & $E V I=\frac{2.5 \times\left(\rho_{2}-\rho_{1}\right)}{\left(\rho_{2}+6 \times \rho_{1}-7.5 \times \rho_{3}+1\right)}$ & Huete et al. (2002) \\
\hline Soil Adjusted Vegetation Index & $S A V I=(1+0.5) \frac{\left(\rho_{2}-\rho_{1}\right)}{\left(\rho_{2}+\rho_{1}+0.5\right)}$ & Huete (1988) \\
\hline $\begin{array}{l}\text { Visible Atmospherically Resistant } \\
\text { Index }\end{array}$ & $V A R I=\frac{\rho_{4}-\rho_{1}}{\rho_{4}+\rho_{1}-\rho_{3}}$ & Gitelson et al. (2002) \\
\hline Vegetation Index — Green & VIGREEN $=\frac{\rho_{4}-\rho_{1}}{\rho_{4}+\rho_{1}}$ & Tucker (1979) \\
\hline
\end{tabular}

\subsection{Statistical analysis}

The temporal variability of LFMC monitored during the field sampling was assessed and compared with the temporal profiles of the SI derived from satellites images. Linear regression was used to assess the potential of each SI for LFMC estimation, analysing the perfomance of spectral information derived from MODIS and Sentinel-2 independently.

In addition, multiple regression models combining different SI were assessed, comparing the results obtained from both sensors. Colinearity was checked, rejecting models with variance inflation factor (VIF) $>5$ for any variable included in the model. Evaluation metrics included coefficiente of determination $\left(\mathrm{R}^{2}\right)$, mean absolute error (MAE), and root mean square error (RMSE). The adjusted $\mathrm{R}^{2}$ value was used in order to compared goodness-of-fit between models with different number of input variables.

\section{Results}

\subsection{MODIS images}

Most of the SI derived from MODIS ( $\mathrm{n}=62$ ) showed a significant correlation with LFMC data (Table 2). The best indices were EVI, VARI, and VIGREEN $\left(\mathrm{R}^{2}=0.83, \mathrm{MAE}=12 \%, \mathrm{RMSE}=15 \%\right)$, followed by NDVI and SAVI $\left(\mathrm{R}^{2}=0.76\right.$, MAE $=14 \%$, RMSE $\left.=18 \%\right)$. NDWI showed a moderate correlation with field data $\left(\mathrm{R}^{2}=0.61, \mathrm{MAE}=17 \%\right.$, $\left.\mathrm{RMSE}=22 \%\right)$, whereas NDII6, NDII7 and GVMI had the lower correlation and higher errors $\left(\mathrm{R}^{2}<0.56\right.$, MAE $\left.>20 \%, \mathrm{RMSE}>24 \%\right)$.

A significant multivariate model was found including NDVI and VARI, with a slight increase in prediction accuracy compared to simple regression models $\left(\mathrm{R}^{2}=0.85\right.$ with $\mathrm{MAE}=11 \%$ and RMSE=14\%). 
Table 2 - Results of the most significant linear regression models to estimate LFMC from MODIS and Sentinel-2 data. MAE, mean absolute error; RMSE, root mean square error.

\begin{tabular}{llcccc}
\hline Sensor & Model & $\mathbf{R}^{\mathbf{2}}$ (adjusted) & p-value & MAE (\%) & RMSE (\%) \\
\hline \multirow{6}{*}{ MODIS } & 0.756 & $<0.0001$ & 14.190 & 17.816 \\
& NDVI & 0.553 & $<0.0001$ & 20.356 & 24.142 \\
& NDII6 & 0.469 & $<0.0001$ & 22.286 & 26.314 \\
& GDII7 & 0.553 & $<0.0001$ & 20.356 & 24.142 \\
& NDWI & 0.611 & $<0.0001$ & 17.218 & 22.509 \\
& EVI & 0.823 & $<0.0001$ & 12.611 & 15.202 \\
& SAVI & 0.756 & $<0.0001$ & 14.190 & 17.816 \\
& VARI & 0.832 & $<0.0001$ & 12.220 & 14.799 \\
& VIGREEN & 0.823 & $<0.0001$ & 12.477 & 15.179 \\
& NDVI, VARI & 0.847 & $<0.0001$ & 11.283 & 13.987 \\
\hline \multirow{5}{*}{ Sentinel-2 } & NDVI & 0.619 & $<0.0001$ & 14.457 & 18.119 \\
& NDII6 & 0.565 & $<0.0001$ & 15.302 & 19.362 \\
& EVI & 0.712 & $<0.0001$ & 12.539 & 15.758 \\
& SAVI & 0.588 & $<0.0001$ & 14.897 & 18.840 \\
& VARI & 0.717 & $<0.0001$ & 13.433 & 15.616 \\
& VIGREEN & 0.670 & $<0.0001$ & 14.144 & 16.864 \\
& NDVI, VARI & 0.764 & $<0.0001$ & 12.045 & 14.054 \\
\hline
\end{tabular}

\subsection{Sentinel-2 images}

For Sentinel-2 $(\mathrm{n}=35)$, the best indices were VARI $\left(\mathrm{R}^{2}=0.72, \mathrm{MAE}=13 \%\right.$, RMSE $\left.=16 \%\right)$, EVI $\left(\mathrm{R}^{2}=0.71, \mathrm{MAE}=13 \%, \mathrm{RMSE}=16 \%\right)$, VIGREEN $\left(\mathrm{R}^{2}=0.67, \mathrm{MAE}=14 \%, \mathrm{RMSE}=17 \%\right)$ and NDVI $\left(\mathrm{R}^{2}=0.62, \mathrm{MAE}=14 \%\right.$, $\left.\mathrm{RMSE}=18 \%\right)$. The lower correlations were found for NDII6 and SAVI $\left(\mathrm{R}^{2}<0.59, \mathrm{MAE}=15 \%, \mathrm{RMSE}=19 \%\right)$.

Similarly to MODIS data, the combination of NDVI and VARI resulted in a significant multivariate model that increased the performance of simple regression models $\left(\mathrm{R}^{2}=0.76, \mathrm{MAE}=12 \%\right.$, RMSE $=14 \%$ ). Figure 1 depicts NDVI and VARI values derived from both satellites compared to LFMC during the study period.

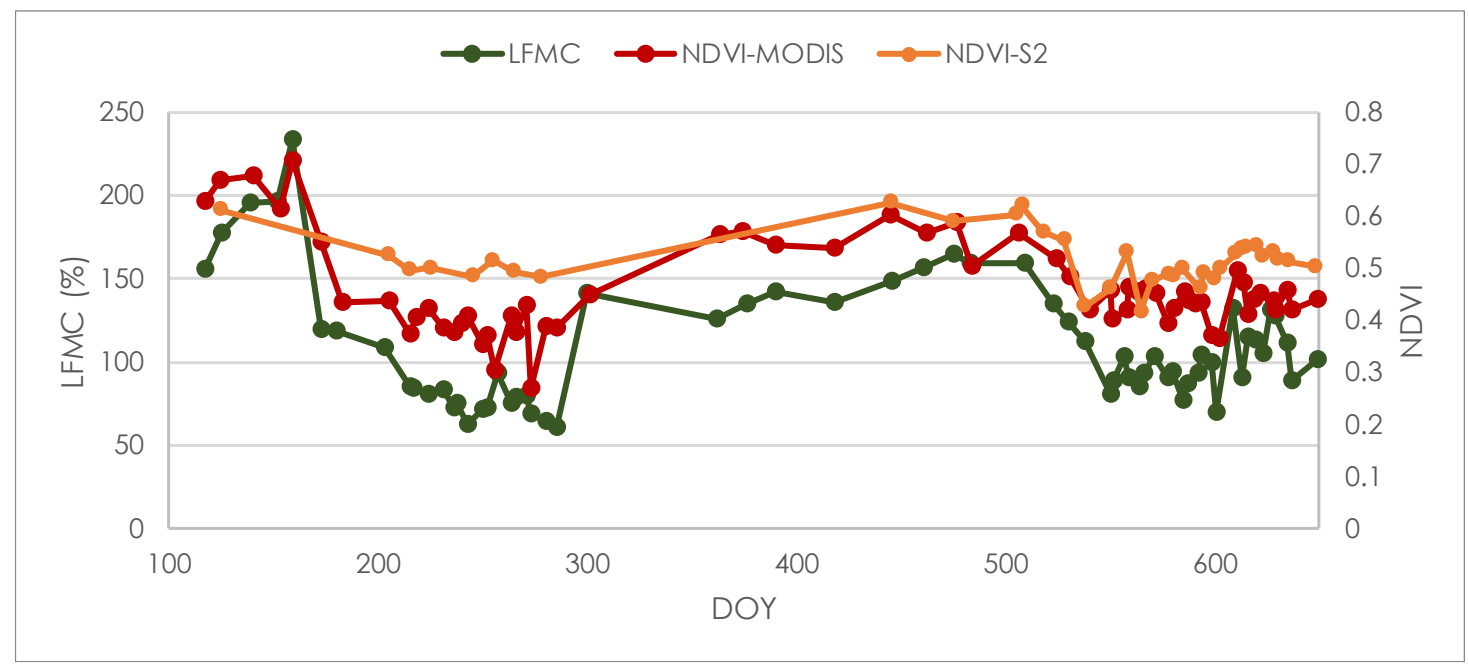




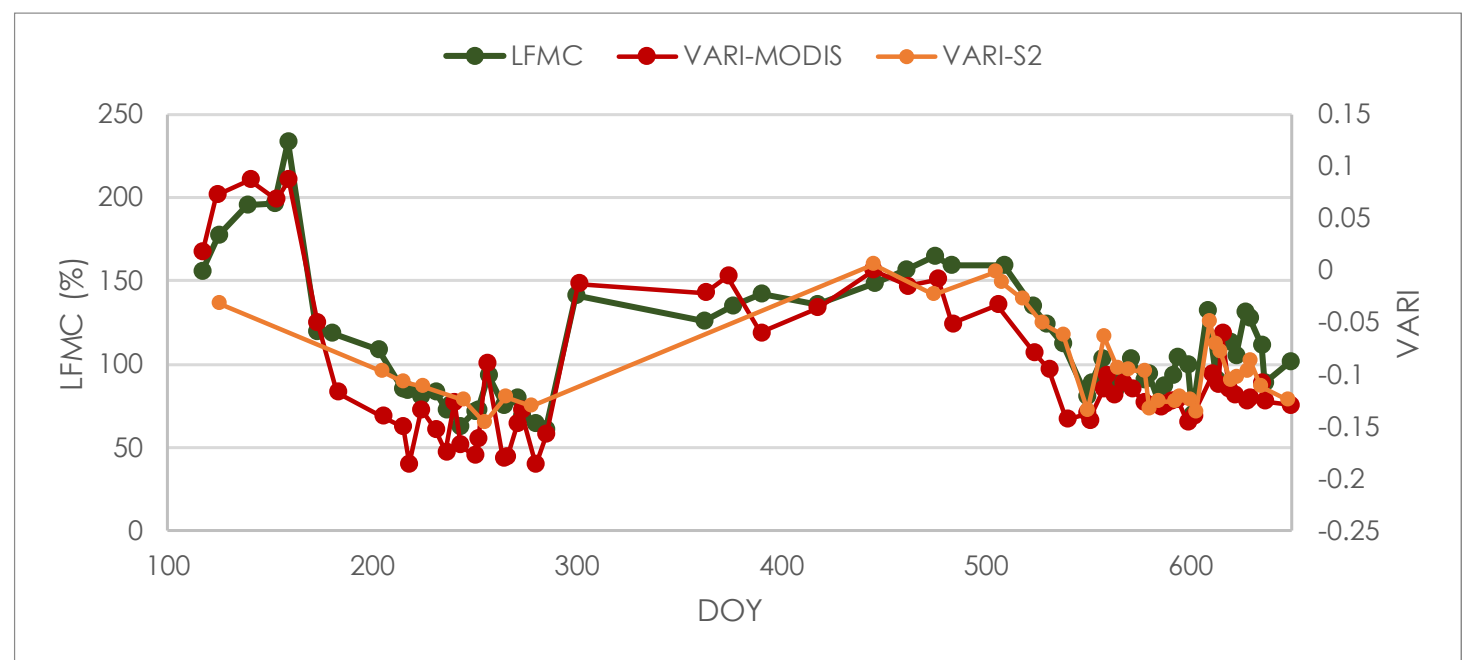

Figure 1 - Comparison of LFMC vith NDVI and VARI derived from MODIS and Sentinel-2 in Cistus ladanifer shrubland, from 24 April 2016 (DOY = 117) to 10 October 2017 (DOY = 649).
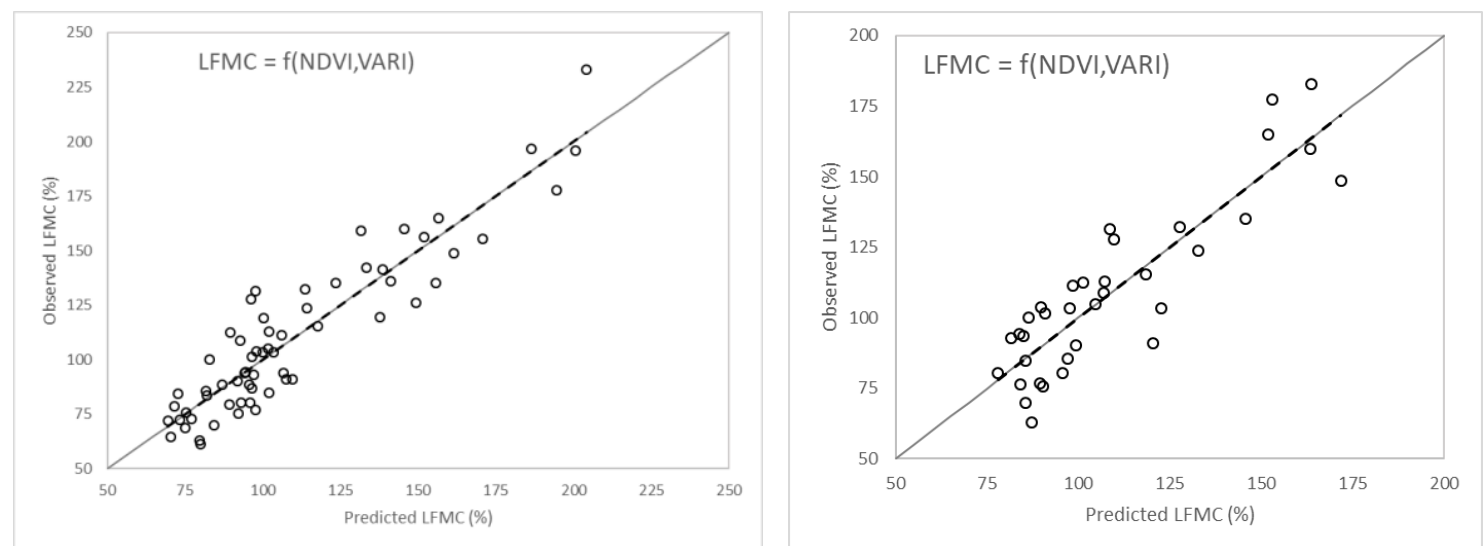

Figure 2 - Observed vs predicted values of LFMC for the best models obtained for MODIS (left, n=62) and Sentinel-2 (right, $n=35$ ) data.

\section{Discussion}

As reported in previous works, this study shows that spectral vegetation indices are an efficient means of obtaining empirical information related to LMFC from multispectral sensors (Yebra et al. 2013). Our results indicate that MODIS and Sentinel-2 images provide similar results for the SI tested (Table 2, Figure 2). The slightly better performance of most SI in the coarser resolution images could be partly due to the lower number of images available from Sentinel-2 for the study period. This limitation specially affected 2016 dataset, with only 8 cloud-free images found compared to 26 from MODIS. However, 27 images from Sentinel-2 were available in 2017 compared to 36 from MODIS. Our results suggest that longer time series may be used in future Sentinel-2 models to better account for the temporal variability of LFMC. This should not prevent the use of spectral information derived from Sentinel-2 images as, with both satellites 2A and 2B fully operational, it is currently possible to produce LFMC estimations every 5 days. However, MODIS still have higher potential in terms of temporal resolution compared to Sentinel-2, which may be a constraint when trying to achieve daily operational products at a finer spatial resolution.

We found that VARI was the SI showing the higher correlation with field measurements of LFMC (Table 2). Regarding MODIS images, previous authors also highlight VARI as the best indicator of LFMC variability in shrubland species compared to other SI (Stow et al. 2006, Peterson et al. 2008, 
Caccamo et al. 2012, Fan et al. 2018). Stow et al. (2006) and Peterson et al. (2008) reported $\mathrm{R}^{2}$ between 0.74 and 0.93 depending on the chaparral sampling site. Caccamo et al. (2012) found lower prediction capacity of VARI with only 0.42 , but mixing different types of vegetation. Our results are in general agreement with these authors, finding $\mathrm{R}^{2}$ of 0.83 for MODIS data. However, it should be highlighted that all these authors used MODIS composite products (generally 8-days composites) compared to the 1-day images used in the present study. Avoiding the use of a composite product in our study reduced the number of available cloud-free images to compare field data $(n=81)$ with spectral information $(\mathrm{n}=62$ for MODIS). However, this choice was deliberately done in order to test the ability of near realtime daily images (only up to two days timelag to sampling date) for LFMC estimation, which is a critical aspect for models to be include in any operational system for wildfire risk assessment.

The best multivariate models combined the same spectral indices (VARI and NDVI) in both type of images. In Australia, Caccamo et al. (2012) suggested NDII6 for improving performance in a multivariate model derived to estimate LFMC from MODIS in shrubland and heathland. Stow et al. (2006) found the best multivariate model combining VARI with NDWI in California chaparral, whereas Peterson et al.(2008) reported better results with VARI and VIGREEN for the same type of shrubland. In our case, VIGREEN also had a strong correlation in the simple models, but NDII6 and NDWI were among the indices with lower correlation with LFMC data. Both VARI and NDVI measure greenness variability, whereas NDWI and NDII6 directly account for water content variations. Although greenness indices do not include water absorption bands, they can be used as an indirect estimation of water content since moisture variations affect chlorophyll activity, which is the case of C.ladanifer (Yebra et al. 2008).

Despite Sentinel-2 provided a slightly lower accuracy, LFMC prediction errors were very similar in the best multivariate model, with mean absolute error of $12 \%$ compared to $11 \%$ of MODIS (Table 2). According to fire management services, these are good results taking into account that $10 \%$ errors in LFMC estimation from field measurements are generally acceptable. Nevertheless, the proposed models should be validated with 2018 data in the same sampling area, in order to assess the sensitivity of both sensors to monitor seasonal and interannual variability of LFMC. Empirical models are also known to have limitations in terms of its ability for extrapolationg accurate results to different sites compared to RTM models (Yebra et al. 2008). However some authors reported moderately good model results for different sites with the same type of vegetation (Stow et al. 2006, Peterson et al. 2008, Caccamo et al. 2012). Hence, further comparison with similar shrubland areas would be highly recommended in order to test limitations when applying these models in other monospecific $C$. ladanifer shrubland.

\section{Conclusions}

This work compares the capacity of empirical models for LFMC estimation in Cistus ladanifer shrubland from two different type of satellite sensors: MODIS and Sentinel-2. MODIS provides daily estimates at a coarser spatial resolution whereas Sentinel-2 can provide higher spatial accuracy every 5 days. Despite both sensors provide images at different spatial and temporal resolution, this study showed similar results in terms of the most relevant spectral indices and model performance. The combination of VARI and NDVI provided the best models for both sensors tested. The proposed models derived from 1-day images should be validated with indepedent datasets and with longer time series. However, results suggest that both sensors could be used for near real-time estimation of LFMC in monospecific $C$. ladanifer shrubland. This study contributes to improve monitoring of the variability of LFMC during the year based on non-composite products, helping the integration of remote sensing data on wildfire danger rating systems. 


\section{Acknowledgements}

This study is part of a broader research performed within the frame of GEPRIF project (RTA201400011-C06-06) co-funded by INIA (Spanish National Research Institute for Agriculture) and the EU through the FEDER program. Eva Marino's participation is supported by a postdoctoral grant from the Spanish Ministry of Economy and Competitiveness (Torres-Quevedo program), which is partially funded by the European Social Fund (ESF) from the European Commission. We acknowledge the firefighting service from Comunidad de Madrid for providing field data.

\section{References}

Caccamo G, Chisholm LA, Bradstock RA, Puotinen ML, Pippen BG (2012) Monitoring live fuel moisture content of heathland, shrubland and sclerophyll forest in south-eastern Australia using MODIS data. International Journal of Wildland Fire 21, 257-269.

Ceccato P, Flasse S, Gregoire JM (2002) Designing a spectral index to estimate vegetation water content from remote sensing data: Part 2. Validation and applications. Remote Sensing of Environment 82, 198-207.

Chuvieco E, Cocero D, Riaño D, Martín MP, Martínez-Vega J, de la Riva J, Pérez F(2004) Combining NDVI and surface temperature for the estimation of live fuel moisture content in forest fire danger rating. Remote Sensing of Environment 92, 322-331.

Chuvieco E, Aguado I, Jurdao S, Pettinari ML, Yebra M, Salas J, Hantson S, de la Riva J, Ibarra P, Rodrigues M, Echevarría M, Azqueta D, Román MV, Bastarrika A, Martínez S, Redondo C, Zapico E, Martínez-Vega FJ (2014) Integrating geospatial information into fire risk assessment. International Journal of Wildland Fire 23, 606-619.

Dennison PE, Roberts DA, Peterson SH, Rechel J (2005) Use of Normalized Difference Water Index for monitoring live fuel moisture. International Journal of Remote Sensing 26, 1035-1042.

Fan L, Wigneron JP, Xiao Q, Al-Yaari A, Wen J, Martin-St Paul N, Dupuy JL, Pimont F, Al Bitar A, Fernandez-Moran R, Kerr YH (2018) Evaluation of microwave remote sensing for monitoring live fuel moisture content in the Mediterranean region. Remote Sensing of Environment 205, 210-223.

Gao BC (1996) NDWI. A normalized difference water index for remote sensing of vegetation liquid water from space. Remote Sensing of Environment 58, 257-266.

Garcia M, Chuvieco E, Nieto H, Aguado I (2008) Combining AVHRR andmeteorological data for estimating live fuelmoisture content. Remote Sensing of Environment 112, 3618-3627.

Gitelson A, Kaufmam JY, Stark R, Rundquist D (2002) Novel algorithms for remote estimation of vegetation fraction. Remote Sensing of Environment 80, 76-87.

Hao XJ, Qu JJ (2007) Retrieval of real-time live fuel moisture content using MODIS measurements. Remote Sensing of Environment 108, 130-137.

Hardisky MA, Klemas V, Smart RM (1983) The influence of soil salinity, growth form, and leaf moisture on the spectral radiance of Spartina alterniflora canopies. Photogrammetric Engineering and Remote Sensing 49, 77-83.

Huete AR (1988) A soil-adjusted vegetation index (SAVI). Remote Sensing of Environment 25, 295309.

Huete A, Didan K, Miura T, Rodriguez EP, Gao X, Ferreira LG (2002) Overview of the radiometric and biophysical performance of the MODIS vegetation indices. Remote Sensing of Environment 83, 195-213.

Jurdao S, Yebra M, Guerschman JP, Chuvieco E (2013) Regional estimation of woodland moisture content by inverting Radiative Transfer Models. Remote Sensing of Environment 132, 59-70. 
Louis J, Debaecker V, Pflug B, Main-Knorn M, Bieniarz J, Mueller-Wilm U, Cadau E, Gascon F (2016) Sentinel-2 Sen2Cor: L2A Processor for Users. In: L. Ouwehand L (ed), Proceedings of the Living Planet Symposium, 9-13 May 2016, Prague, Czech Republic. ESA-SP Volume 740, p.91. ISBN: 978-92-9221-305-3.

Marino E, Dupuy JL, Pimont F, Guijarro M, Hernando C, Linn R (2012) Fuel bulk density and fuel moisture content effect on fire rate of spread: a comparison between FIRETEC model predictions and experimental results in shrub fuels. Journal of Fire Sciences 30(4), 277-299.

Nolan RH, Resco de Dios V, Boer MM, Caccamo G, Goulden ML, Bradstock RA (2016) Predicting dead fine fuel moisture at regional scales using vapour pressure deficit from MODIS and gridded weather data. Remote Sensing of Environment 174, 100-108.

Pausas JG, Fernández-Muñoz S (2012) Fire regime changes in the Western Mediterranean Basin: from fuel-limited to drought-driven fire regime. Climatic Change 10, 215-226.

Peterson S, Roberts DA, Dennison PE (2008) Mapping live fuel moisture with MODIS data: A multiple regression approach. Remote Sensing of Environment 112, 4272-4284.

Rouse Jr JW, Haas RW, Schell JA, Deering DH, Harlan JC (1974) Monitoring the vernal advancement and retrogradation (Greenwave effect) of natural vegetation. Type III final report. Greenbelt, MD, USA: NASA/GSFC.

Ruffault J, Curt T, Martin-StPaul NK, Moron V, Trigo RM (2018) Extreme wildfire events are linked to global-change-type droughts in the northern Mediterranean. Natural Hazards and Earth System Sciences 18(3), 847-856.

Stow D, Madhura N, Kaiser J (2006) Time series of chaparral live fuel moisture maps derived from MODIS satellite data. International Journal of Wildland Fire 15, 347-360.

Tanase MA, Panciera R, Lowell K, Aponte C (2015) Monitoring live fuel moisture in semiarid environments using L-band radar data. International Journal of Wildland Fire 24, 560-572.

Tucker CJ (1979) Red and photographic infrared linear combinations for monitoring vegetation. Remote Sensing of Environment 8, 127-150.

Viney NR (1991) A review of fine fuel moisture modelling. International Journal of Wildland Fire 1, 215-234.

Yebra M, Chuvieco E (2009) Linking ecological information and radiative transfer models to estimate fuel moisture content in the Mediterranean region of Spain: Solving the ill-posed inverse problem. Remote Sensing of Environment 113, 2403-2411.

Yebra M, Chuvieco E, Riaño D (2008) Estimation of live Fuel Moisture Content from MODIS images for fire risk assessment. Agricultural and Forest Meteorology 148, 523-536. doi:10.1016/J.AGRFORMET.2007.12.005

Yebra M, Dennison PE, Chuvieco E, Riaño D, Zylstra P, Hunt ER Jr, Danson FM, Qi Y, Jurdao S (2013) A global review of remote sensing of live fuel moisture content for fire danger assessment: Moving towards operational products. Remote Sensing of Environment 136, 455-468. 